\title{
Soil mites (Acari) on plantations of chokeberry and black currant under microirrigation
}

\author{
ANDRZEJ KLIMEK ${ }^{1}$ and STANISŁAW ROLBIECKI ${ }^{2}$ \\ ${ }^{1}$ Division of Agrotourism and Landscape Shaping, Kordeckiego 20, \\ University of Technology and Life Sciences, 85-225 Bydgoszcz, Poland; e-mail: klimek@utp.edu.pl \\ ${ }^{2}$ Department of Land Melioration and Agrometeorology, Bernardyńska 6, \\ University of Technology and Life Sciences, 85-029 Bydgoszcz, Poland; e-mail: rolbs@utp.edu.pl
}

(Received on 17 January 2008; Accepted on 28 November 2009)

\begin{abstract}
Bushes of black currant (Ribes nigrum) were slightly higher and wider, and their leaves had a higher content of major nutrients than chokeberry (Aronia melanocarpa). Soil samples were collected in 2004 , in spring, summer and autumn, i.e. $3 \times 20$ samples from each experimental variant. Three irrigation variants were compared: no irrigation (C), drip irrigation (D), and micro-jet sprinkling (M). In the soil of the black currant plantation, the density of mites was higher (in variants $\mathrm{C}$ and $\mathrm{D}$ ), as compared to the chokeberry plantation. The saprophagous oribatid mites were predominant in the studied mite communities, while Actinedida and Gamasida were less numerous. Oribatid mites were more numerous and more diverse in the black currant plantation than in the chokeberry plantation. The influence of irrigation on the density of oribatid mites was insignificant. In the communities of oribatid mites, Tectocepheus velatus was distinctly predominant on most plots.
\end{abstract}

Keywords: chokeberry, black currant, drip irrigation, micro-jet sprinkling, Acari, Oribatida.

\section{INTRODUCTION}

Chokeberry (Aronia melanocarpa) as well as black currant (Ribes nigrum) are berry bushes. At present, they are important fruit crops because of their economic value (RoLBIECKI 2003) and high nutritive value. Their small soil requirements indicate the possibility of their cultivation also on light soils as well as on very light soils. In such conditions the use of irrigation, especially drip irrigation and micro-jet sprinkling, is necessary.

In the climatic zones with leaf-fall and fruit drop at the end of the growing period, saprophagous species are needed for proper function of the ecosystem. Among the soil mites, especially on forest soils with raw humus, the saprophagous oribatid mites (Oribatida) are distinctly predominant. The density of oribatid mites in soils of pine forests usually reaches several hundred thousand individuals per $\mathrm{m}^{2}$ of soil area (KLIMEK 2000). Occurrence of these mites in the soils under long-term plantations 
of horticultural crop plants, e.g. berry bushes, can be also important, like in the case of soils of forests and newly afforested areas. These mites stimulate organic matter decomposition and interact with soil microorganisms. Oribatid mites can feed on ectomycorrhizal fungi (SCHNEIDER et al. 2005), and can also influence fungal growth and stimulate fungal spread. This is important because mycorrhizal fungi are connected with roots of $95 \%$ of plants. Their positive influence on the growth of plants is commonly known. Mycorrhizal fungi stimulate plant vitality and play a great role in limiting many infections (BADURA 2004).

Mites, especially saprophagous oribatid mites, are regarded as useful bioindicators of the degree of decomposition and biological properties of forest humus (SENICZAK 1979). Therefore, they can be used as bioindicators of the biological status of soils, and of the degree of soil degradation. The aim of this study was to determine: (1) the density and diversity of mites (Acari) in plantations of chokeberry and black currant, with special emphasis on oribatid mites; and (2) the influence of microirrigation on these arthropods.

\section{MATERIAL AND METHODS}

Acarological investigations were carried out in 2004 on the experimental field of the Department of Land Melioration and Agrometeorology at Kruszyn Krajeński near Bydgoszcz (northern Poland). Plantations of chokeberry (established in 1994) and black currant (established in 1991) were chosen for the study. Chokeberry seedlings were spaced $2.4 \mathrm{~m} \times 2 \mathrm{~m}$, whereas black currant seedlings, $2.5 \mathrm{~m} \times 1 \mathrm{~m}$. Before planting them on former arable land, fertilization with cow dung and deep ploughing were applied.

Drip irrigation was applied using Aqua-Trax drip lines (in-line emitters spaced $20 \mathrm{~cm}$ apart). Two drip lines were located along each row of bushes, at a distance of about $30 \mathrm{~cm}$ (one line on each side). Micro-jet sprinkling was applied using Hadar sprinklers (wetting diameter about 2.0-2.5 m).

Frequency of irrigation was established on the basis of soil water potential, determined with the use of tensiometers. During dry periods, drip irrigation was performed every 2-3 days, and micro-jet sprinkling every 4-6 days.

The major potential factors influencing the occurrence of mites were: bush species (chokeberry, black currant) as well as irrigation $(\mathrm{C}=$ control, i.e. without irrigation, $\mathrm{D}=$ drip irrigation, $\mathrm{M}=$ micro-jet sprinkling).

To investigate the occurrence of mites, soil samples were taken 3 times a year: in spring (mid-May), in summer (early August), and in autumn (mid-October). From each variant of the experiment, 60 samples $(3 \times 20)$ were taken. A single sample was $17 \mathrm{~cm}^{2}$ in area and $3 \mathrm{~cm}$ deep. Mites were extracted from the material in highgradient Tullgren funnels, and were next preserved. Oribatid mites were identified to species or genus, including juvenile forms. Other mites were identified to order, according to Hammen's (1972) classification. In total, 3732 Acari (including 2499 Oribatida) were studied.

The density of mites was calculated per $1 \mathrm{~m}^{2}$ of soil. Species diversity of oribatid mites was determined as the total number of species, the mean number of species per 
sample, as well as the Shannon index of species diversity $\left(H^{\prime}\right)$ (MagurRan 1988). The numerical data were $\ln$-transformed $(x+1)$ prior to the statistical analyses (BERTHET \& GERARD 1965). Statistical analyses were conducted with the use of Statistica software. Fisher-Snedecor test was used to determine the significance of the influence of experimental factors, and Tukey test was used to define significant differences between the combinations.

\section{RESULTS}

\section{Soil and climatic conditions}

The experiment was carried out on degraded meadow black earth, formed from coarse sandy soil, on loose sandy soil. Chemical analyses of the soil show that soil reaction $(\mathrm{pH})$ was slightly acidic or acidic, and differences in $\mathrm{pH}$ between chokeberry and black currant plantations were small (Table 1). P content in the investigated area was high or even very high, while $\mathrm{K}$ and $\mathrm{Mg}$ contents ranged from medium to low.

Total rainfall during the growing period (April-September) in 2004 amounted to $244.5 \mathrm{~mm}$, so it was lower than the long-term mean $(281 \mathrm{~mm})$. Mean air temperature for this period was $13.4^{\circ} \mathrm{C}$, so it was $0.7^{\circ} \mathrm{C}$ lower than the long-term mean.

Table 1. Chosen chemical properties of soil under different irrigation systems in plantations of chokeberry and black currant

\begin{tabular}{ccccc}
\hline \multirow{2}{*}{ Soil property } & \multirow{2}{*}{ Species } & \multicolumn{3}{c}{ Treatment } \\
\cline { 3 - 5 } & & $\mathrm{C}$ & $\mathrm{D}$ & $\mathrm{M}$ \\
\hline \multirow{2}{*}{$\mathrm{pH}$ in $1 \mathrm{M} \mathrm{KCl}$} & chokeberry & $4.2(4.0-4.5)$ & $6.4(5.5-7.2)$ & $5.8(4.4-7.2)$ \\
& black currant & $5.1(4.2-5.8)$ & $5.2(4.8-5.6)$ & $6.0(4.8-6.6)$ \\
\hline \multirow{2}{*}{$\mathrm{P}\left(\mathrm{mg} \cdot \mathrm{kg}^{-1}\right)$} & chokeberry & $73(55-93)$ & $93(84-108)$ & $68(58-84)$ \\
& black currant & $100(69-117)$ & $107(76-137)$ & $111(62-161)$ \\
\hline \multirow{2}{*}{$\mathrm{K}\left(\mathrm{mg} \cdot \mathrm{kg}^{-1}\right)$} & chokeberry & $89(33-126)$ & $55(49-66)$ & $60(42-71)$ \\
& black currant & $96(87-108)$ & $84(62-107)$ & $91(58-125)$ \\
\hline \multirow{2}{*}{$\mathrm{Mg}\left(\mathrm{mg} \cdot \mathrm{kg}^{-1}\right)$} & chokeberry & $19(10-27)$ & $47(26-66)$ & $41(10-66)$ \\
& black currant & $16(15-17)$ & $26(24-27)$ & $37(12-54)$ \\
\hline \multirow{2}{*}{$\mathrm{Humus}(\%)$} & chokeberry & $1.56(0.66-2.45)$ & $1.37(0.85-1.90)$ & $1.12(0.95-1.30)$ \\
& black currant & $1.24(0.80-1.68)$ & $1.13(0.34-1.93)$ & $1.14(1.0-1.29)$ \\
\hline
\end{tabular}

$\mathrm{C}=$ control (no irrigation), $\mathrm{D}=$ drip irrigation, $\mathrm{M}=$ micro-jet sprinkling

\section{Irrigation and growth of bushes}

Total irrigation rates in 2004 amounted to 93 and $87 \mathrm{~mm}$ in drip irrigation, and to 131 and $127 \mathrm{~mm}$ in micro-jet sprinkling, for chokeberry and black currant, respectively. 
Bushes of black currant were slightly higher and wider than those of chokeberry. The mean content of particular nutrients in leaves was also higher in black currant than in chokeberry (Table 2).

Table 2. Mean indices of bush growth $(\mathrm{cm})$ and nutrient content of leaves ( $\%$ dry weight) under different irrigation systems in plantations of chokeberry and black currant

\begin{tabular}{cccccc}
\hline \multirow{2}{*}{ Index } & Species & \multicolumn{3}{c}{ Treatment } \\
\cline { 3 - 5 } & chokeberry & 133.9 & 152.6 & 156.7 & mean \\
\hline \multirow{2}{*}{ Height $(\mathrm{cm})$} & black currant & 133.5 & 156.4 & 161.0 & 150.3 \\
\hline \multirow{2}{*}{ Width $(\mathrm{cm})$} & chokeberry & 145.2 & 173.8 & 173.5 & 164.2 \\
& black currant & 144.3 & 182.3 & 185.7 & 170.8 \\
\hline \multirow{2}{*}{$\mathrm{N}(\% \mathrm{DW})$} & chokeberry & 2.29 & 2.10 & 1.85 & 2.08 \\
& black currant & 2.21 & 2.14 & 2.13 & 2.16 \\
\hline \multirow{2}{*}{$\mathrm{P}(\% \mathrm{DW})$} & chokeberry & 0.29 & 0.27 & 0.29 & 0.28 \\
& black currant & 0.52 & 0.57 & 0.61 & 0.57 \\
\hline \multirow{2}{*}{$\mathrm{K}(\% \mathrm{DW})$} & chokeberry & 1.46 & 1.31 & 1.54 & 1.44 \\
\hline \multirow{2}{*}{$\mathrm{Mg}(\% \mathrm{DW})$} & black currant & 2.67 & 2.37 & 2.47 & 2.50 \\
\hline \multirow{2}{*}{ (\%) } & chokeberry & 0.20 & 0.23 & 0.19 & 0.21 \\
\hline
\end{tabular}

$\mathrm{C}=$ control (no irrigation), $\mathrm{D}=$ drip irrigation, $\mathrm{M}=$ micro-jet sprinkling

\section{Abundance of mites in general}

In the study area, the density of mites was relatively low, ranging from 5080 to 7600 individuals $\cdot \mathrm{m}^{-2}$. The black currant plantation was characterized by significantly more numerous mites than the chokeberry plantation in treatments $\mathrm{C}$ and $\mathrm{D}$ (Table 3 ). Statistical analyses showed that the use of microirrigation did not affect significantly the abundance of mites, but bush species influenced this index.

In the studied communities of mites, the saprophagous oribatid mites were distinctly predominant (mean $67 \%$ of total catch). Relatively numerous were also Actinedida (24.5\%) and Gamasida (5.5\%). No influence of irrigation on the density of oribatid mites was detected, but this index was significantly dependent on bush species. Treatments $\mathrm{C}$ and $\mathrm{D}$ on the black currant plantation were characterized by significantly higher densities of Oribatida than on the chokeberry plantation.

\section{Diversity and abundance of oribatid mites}

In the study area, a total of 31 species of oribatid mites were found. In the chokeberry plantation, the number of species ranged from 15 to 19 , depending on experimental treatment, but in case of black currant, species were more numerous, ranging 
Table 3. Mean abundance of mites (in $10^{3}$ individuals $\cdot \mathrm{m}^{-2}$ ) and species diversity of Oribatida under different irrigation systems in plantations of chokeberry and black currant

\begin{tabular}{|c|c|c|c|c|c|c|c|c|c|}
\hline \multirow{2}{*}{$\begin{array}{l}\text { Index and group } \\
\text { of mites }\end{array}$} & \multicolumn{3}{|c|}{ Chokeberry } & \multicolumn{3}{|c|}{ Black currant } & \multirow{2}{*}{$\mathrm{S}$} & \multirow{2}{*}{ I } & \multirow{2}{*}{$\mathrm{S} \times \mathrm{I}$} \\
\hline & $\mathrm{C}$ & D & M & $\mathrm{C}$ & D & M & & & \\
\hline \multicolumn{10}{|l|}{ Abundance } \\
\hline Acari & 5.08 & 5.40 & $6.37^{\mathrm{A}}$ & $6.46^{\mathrm{B}}$ & $7.60^{\mathrm{B}}$ & 6.54 & $<0.001$ & ns & ns \\
\hline Acaridida & 0.03 & - & 0.03 & 0.04 & 0.06 & 0.05 & ns & ns & ns \\
\hline Actinedida & 1.63 & 1.40 & 1.55 & 1.33 & 1.74 & 1.52 & ns & ns & $\mathrm{ns}$ \\
\hline Gamasida & 0.20 & 0.29 & $0.52^{\mathrm{A}}$ & 0.37 & 0.39 & 0.30 & $\mathrm{~ns}$ & $\mathrm{~ns}$ & 0.044 \\
\hline Tarsonemida & 0.11 & 0.27 & 0.18 & 0.13 & 0.12 & 0.11 & ns & $\mathrm{ns}$ & ns \\
\hline Oribatida & 3.11 & 3.43 & 4.09 & $4.59^{\mathrm{B}}$ & $5.29^{\mathrm{B}}$ & 4.57 & $<0.001$ & $\mathrm{~ns}$ & ns \\
\hline $\begin{array}{l}\text { Chamobates } \\
\text { cuspidatiformis } \\
\text { Trägårdh }\end{array}$ & 0.99 & 1.33 & 1.27 & 0.69 & 0.84 & $0.55^{\mathrm{B}}$ & 0.005 & ns & ns \\
\hline $\begin{array}{l}\text { Scutovertex } \\
\text { sculptus } \text { Michael }\end{array}$ & 0.46 & 0.19 & 0.21 & 0.27 & $0.02^{\mathrm{AB}}$ & 0.11 & 0.005 & 0.003 & ns \\
\hline $\begin{array}{l}\text { Tectocepheus } \\
\text { velatus Michael }\end{array}$ & 0.93 & $1.65^{\mathrm{A}}$ & $1.94^{\mathrm{A}}$ & $1.66^{\mathrm{B}}$ & 2.11 & $2.44^{\mathrm{A}}$ & 0.006 & 0.001 & ns \\
\hline \multicolumn{10}{|l|}{ Oribatida } \\
\hline Species number & 19 & 15 & 18 & 21 & 18 & 20 & - & - & - \\
\hline Species per sample & 2.08 & 2.12 & 2.32 & $3.17^{\mathrm{B}}$ & $2.80^{\mathrm{B}}$ & $2.92^{\mathrm{B}}$ & $<0.001$ & $\mathrm{~ns}$ & ns \\
\hline Shannon index & 1.86 & 1.25 & 1.54 & 2.14 & 1.89 & 1.73 & - & - & - \\
\hline
\end{tabular}

${ }^{\mathrm{A}}=$ significant differences between $\mathrm{C}$ and $\mathrm{D}$ or $\mathrm{M}$ at $P<0.05 ;{ }^{\mathrm{B}}=$ significant differences between chokeberry and black currant plots at $P<0.05 ; \mathrm{C}=$ control (no irrigation), $\mathrm{D}=$ drip irrigation, $\mathrm{M}=$ micro-jet sprinkling; $\mathrm{S}=$ effect of bush species ( $P$ values $) ; \mathrm{I}=$ effect of irrigation ( $P$ values $)$

from 18 to 21 . Bush species was the only factor that influenced the diversity of oribatid mites - the mean numbers of species per sample in treatments C, D and M of black currant were higher than in those of chokeberry. The Shannon index of species diversity $\left(H^{\prime}\right)$ ranged from 1.25 to 1.86 in the chokeberry plantation, and in the plantation of black currant it was insignificantly higher: from 1.73 to 2.14.

In the communities of oribatid mites, Tectocepheus velatus Michael, 1880, was distinctly predominant, except for plot $\mathrm{C}$ of chokeberry. Density of this species was affected by both experimental factors (treatments and species). The use of irrigation, especially micro-jet sprinkling, significantly increased its density.

The density of another species of oribatid mites - Chamobates cuspidatiformis Trägårdh, 1904, was lower than that of Tectocepheus velatus. Chamobates cuspidatiformis preferred the plantation of chokeberry.

Occurrence of Scutovertex sculptus Michael, 1879, is also interesting. Both experimental factors (treatments and species) influenced its density. This species preferred non-irrigated plots in the chokeberry plantation. 


\section{DISCUSSION}

The mean height of chokeberry bushes ranged from 133.9 to $156.7 \mathrm{~cm}$, but the lowest bushes were found on non-irrigated plots. These results confirm that scarcity of water during the growing period causes poor growth of chokeberry bushes (CHLEBOWSKA \& SMOLARZ 1988). Irrigation significantly increased the height of chokeberry bushes, to $152.6-156.7 \mathrm{~cm}$.

The height of black currant bushes ranged from $133.5 \mathrm{~cm}$ to $161 \mathrm{~cm}$, depending on the experimental variant.

In our experiment, irrigation significantly increased the growth indices of black currant bushes. This is important because the growth of black currant bushes is positively correlated with their fruit yield (HOFMANN 1991).

The abundance of mites noted in soils of chokeberry and black currant plantations was similar to the density of these arthropods in the soil of the neighbouring fallow land (3460-6650 individuals $\cdot \mathrm{m}^{-2}$ ) (RoLBIECKI et al. 2006) and it was slightly lower than that noted in the forest soil of a 7-year-old pine plantation (10410 individuals $\cdot \mathrm{m}^{-2}$ ) (KLIMEK 2004). The irrigation used in this experiment did not affect significantly the abundance of mites. The same microirrigation methods (drip and micro-jet) did not affect significantly the abundance of soil mites also in an experiment on 1-2-year-old Scots pine seedlings grown on the same field (RoLBIECKI et al. 2005, ROLBIECKI et al. 2006). In contrast, a positive impact of irrigation on the abundance of these arthropods was noted in a forest nursery (KLIMEK et al. 2008).

Higher abundance of mites in the plantation of black currant, as compared to that of chokeberry, can be a result of bush size, because black currant bushes were higher and wider. Higher bushes supply larger biomass of leaf fall, securing attractive food for saprophagous mites. In addition, leaves of black currant contained more nutrients than those of chokeberry.

Among recorded mites, 2/3 were oribatid mites classified as saprophages. Their share in communities of mites was similar to that noted in forest soils under birch stands and pine stands (KLIMEK \& SENICZAK 2002), but their abundance in this experiment was many times lower.

The study showed that the abundance and species diversity of oribatid mites were dependent on bush species - they were significantly higher in the black currant plantation. Irrigation did not affect these indices. However, in the forest tree nursery the same irrigation systems had a positive influence on oribatid mites in pine plantations. In particular, the positive effect on the abundance and the species diversity of this group of mites was noted in case of joint influences from micro-jet sprinkling and organic fertilization in birch plantations (ROLBIECKI et al. 2005). Results published by other authors indicated that in most cases irrigation positively affected the abundance of oribatid mites and also other soil animals (LINDBERG et al. 2002, TsiAfouli et al. 2005).

Tectocepheus velatus was the most abundant species of oribatid mites in the investigated area. This is a common soil species occurring in different biotopes (Weigmann \& KRATZ 1981), but it prefers acid soils (HÅgVAR \& KJøndal 1981, HÅGVAR 1984). The positive influence of irrigation on this species was also detected in 
another trial with Scots pine on the neighbouring plot mulched with forest soil (RoLBIECKI et al. 2005). Response to irrigation of Scutovertex sculptus was different. The negative reaction of this species to microirrigation can be connected with its preference for dry sites characterized by great insolation and a low plant coverage (Table 2), e.g. industrial dumps (KLIMEK et al. 1991, Skubata 1999) or fallow land (Rolbiecki et al. 2006).

\section{REFERENCES}

BADURA L. 2004. Czy znamy wszystkie uwarunkowania funkcji mikroorganizmów w ekosystemach lądowych? [Do we know the all conditioning of functions of microorganisms in land ecosystems?] Kosmos - Probl. Nauk Biol. 53: 373-379.

Berthet P., Gerard G. 1965. A statistical study of microdistribution of Oribatei (Acari) I. The distribution pattern. Oikos. 16: 214-227.

ChlebowsKa D., Smolarz K. 1988. Wstępne wyniki plonowania aronii w ZD Dąbrowicach [Preliminary results of chokeberry yielding in Experimental Station Dąbrowice]. Sad Nowocz. 11: 21-24.

HÅGVAR S. 1984. Six common mite species (Acari) in Norwegian coniferous forest soils: Relations to vegetation types and soil characteristics. Pedobiologia 27: 355-364.

HÅgVar S., KJøndal B. R. 1981. Effects of artificial acid rain on the microarthropod fauna in the decomposing birch leaves. Pedobiologia. 22: 409-422.

Hammen L. 1972. A revised classification of the mites (Arachnidea, Acarida) with diagnoses, a key, and notes on phylogeny. Zool. Mededelingen. 47: 273-292.

HofmanN S. 1991. Bewässerung bei Roter und Schwarzer Johannisbeere. Gartenbau Magazin. 38: $33-35$.

KLIMEK A. 2000. Wpływ zanieczyszczeń emitowanych przez wybrane zakłady przemysłowe na roztocze (Acari) glebowe młodników sosnowych, ze szczególnym uwzględnieniem mechowców (Oribatida) [Impact of pollutants emitted by factories selected on the young Scots pine forests soil mites (Acari), Oribatida in particular]. Rozprawy 99: 1-93, Wyd. Uczln. ATR, Bydgoszcz.

KLIMEK A. 2004. Akarofauna (Acari) glebowa wybranych stref ekotonowych Borów Tucholskich [Soil mites (Acari) of some ecotone in Tuchola forest]. In: Diagnozowanie stanu środowiska. Metody badawcze - prognozy (Borsuk S. Ed.), pp. 84-93, BTN, Bydgoszcz.

Klimek A., Rolbiecki S., Rolbiecki R., Hilszczańska D., Malczyk P. 2008. Impact of chosen bare root nursery practices in Scots pine seedling quality and soil mites (Acari). Pol. J. Environ. Stud. 17: 247-255.

KLimek A., Seniczak S. 2002. Soil mites (Acari) of the ecotone between the scots pine and birch forests in Tuchola forest. In: Postępy polskiej akarologii (IgnAtowicz S., Ed.), pp. 151-162, Wyd. SGGW, Warszawa.

Klimek A., Seniczak S., Żelazna E., Dąbrowska B. 1991. Akarofauna (Acari) skarp osadników produktów odpadowych Janikowskich Zakładów Sodowych [The fauna of mites (Acari) of the escarps of 'white seas' near Janikowo Soda Factory]. Zesz. Nauk. ATR w Bydgoszczy. Zootechnika. 22: 151-165.

Lindberg N., Bengtsson J. B., Persson T. 2002. Effects of experimental irrigation and drought on the composition and diversity of soil fauna in a coniferous stand. J. Appl. Ecol. 39: 924-936.

MagurRan A. E. 1988. Ecological diversity and its measurement. pp.1-179, Chapman \& Hall, London. 
Rolbiecki R., Rolbiecki S., Klimek A., HilszcZańska D. 2005. Wpływ mikronawodnień i nawożenia organicznego na produkcję jednorocznych sadzonek sosny zwyczajnej (Pinus sylvestris L.) na gruncie porolnym obiektu Kruszyn Krajeński z udziałem zabiegu zoomelioracji (badania wstępne) [Effect of microirrigation and organic fertilization on the one-year old seedling production of Scotch pine (Pinus sylvestris L.) on a post-agricultural ground at Kruszyn Krajeński with the use of zoo-melioration (preliminary study)]. Infrastr. i Ekol. Teren. Wiejsk. 4: 131-143.

Rolbiecki R., PodsiadŁo C., Rolbiecki S., Klimek A. 2006. Wpływ mikronawodnień i nawożenia organicznego na produkcję siewek sosny zwyczajnej (Pinus sylvestris L.) na gruncie porolnym $\mathrm{w}$ różnych warunkach meteorologicznych $\mathrm{z}$ udziałem zabiegu zoomelioracji [Effect of microirrigation and organic fertilization on the seedling production of Scots pine (Pinus sylvestris L.) seed-lings on a post-agricultural ground in different meteorological conditions with the use of zoo-melioration]. In: Diagnozowanie stanu środowiska. Metody badawcze prognozy (Borsuk S., Ed.), pp. 33-41, BTN, Bydgoszcz.

RolBIECKI S. 2003. Reakcja trzech gatunków roślin jagodowych uprawianych na bardzo lekkiej glebie na mikronawodnienia [The response of the three berry-bearing species grown on a very light soil to microirrigation]. Rozprawy 108: 1-87, Wyd. Uczeln. ATR, Bydgoszcz.

Rolbiecki S., Rolbiecki R., Klimek A. 2005. Wpływ mikronawodnień i nawożenia organicznego na produkcję jednorocznych sadzonek brzozy brodawkowatej (Betula verrucosa Ehrh.) $\mathrm{z}$ udziałem zabiegu zoomelioracji [Effect of microirrigation and organic fertilization on oneyear old seedling production of the verrucose birch at zoo-melioration treatment applied]. Zesz. Probl. Post. Nauk Rol. 506: 345-353.

Rolbiecki S., Stypczyńska Z., Kuimek A., Długosz J., Rolbiecki R. 2006. Roślinność i niektóre właściwości odłogowanej gleby piaszczystej uprzednio użytkowanej rolniczo w warunkach deszczowania [Flora and some proporties of fallow soil which was previously under arable cultivation in conditions of sprinkler irrigation]. Infrastr. i Ekol. Teren. Wiejsk. 2: 183-194.

Schneider K., Renker C., Maraun M. 2005. Oribatid mite (Acari, Oribatida) feeding on ectomycorrhizal fungi. Mycorrhiza. 16: 67-72.

SENICZAK S. 1979. Fauna mechowców (Acari, Oribatei) jako indykator biologicznych właściwości próchnic leśnych [Moss mites (Acari, Oribatei) as indicator of the biological properties of forest humus]. Pr. Kom. Nauk. PTG 5/37: 157-166.

Skubata P. 1999. Colonization of a dolomitic dump by oribatid mites (Acari, Oribatida). Pedobiologia. 43: 145-159.

Tsiafouli M. A., Kallimanis A. S., Katana E., Stamou G. P., Sgardelis S. P. 2005. Responses of soil microarthropods to experimental short-term manipulations of soil moisture. Appl. Soil Ecol. 29: 17-26.

Weigmann G., Kratz W. 1981. Die deutschen Hornmilbenarten und ihre ökologische Charakteristik. Zool. Beitr. 27: 459-489 